\title{
Psychopathology of Joseph Stalin
}

\author{
Marina Stal \\ Teacher's College, Columbia University, New York, USA \\ Email: mstal3965@gmail.com
}

Received July 20 $0^{\text {th }}$ 2013; revised August $18^{\text {th }}$, 2013; accepted September $12^{\text {th }}, 2013$

\begin{abstract}
Copyright (c) 2013 Marina Stal. This is an open access article distributed under the Creative Commons Attribution License, which permits unrestricted use, distribution, and reproduction in any medium, provided the original work is properly cited.
\end{abstract}

\begin{abstract}
Between 1928 and 1953, Joseph Stalin was the undisputed totalitarian dictator of the former Soviet Union whose "reign of fear" continues to maintain its egregious reputation. An examination of Stalin's documented behaviors attempts to evaluate any signs of psychopathology in accordance with DSM-IV-TR criteria. Evidence of a troubled upbringing, depression, paranoia, and alcohol abuse suggests psychopathology as an implicating factor behind Stalin's actions. Utilizing such a perspective may allow for future distinctions of individuals deemed responsible for horrendous atrocities.
\end{abstract}

Keywords: Sociopath; Antisocial Personality Disorder; Dictator; Stalin

\section{Rationale for Examining the Psychopathology of Joseph Stalin}

The Holocaust Encyclopedia of the United States Holocaust Memorial Museum provides a concise origin of the term "genocide":

In 1944, a Polish-Jewish lawyer named Raphael Lemkin (1900-1959) sought to describe Nazi policies of systematic murder, including the destruction of the European Jews. He formed the word "genocide... a coordinated plan of different actions aiming at the destruction of essential foundations of the life of national groups, with the aim of annihilating the groups themselves.” The next year, the International Military Tribunal held at Nuremberg, Germany, charged top Nazis with "crimes against humanity." The word "genocide" was included in the indictment.

Subsequent to the Nuremberg Trials, on December 9, 1948, the United Nations approved the Convention on the Prevention and Punishment of the Crime of Genocide. Since then, the United Nations, in accordance with the United States and various other nations, has attempted to apply the information known from previous incidences in a way that would prevent further oppression and death (United Nations, 1951). Unfortunately, there have been more than a number of ethnic, racial, and/or religious purges throughout the world since, revealing that perhaps there is a missing link, or overlooked lesson regarding the reality of contemporary oppression. Unrest in Sri Lanka, Sierra Leone, Chechnya, and numerous other locales are being undermined and categorized as "civil unrest" rather than genocide (Mamdani, 2007). Perhaps a look at the history of such actions from a different perspective will present a distinctive point of view.

It is an undesirable, yet firm, reality that individuals who have obtained power will wish to maintain it; how far some will go to keep hold of said power is where reality becomes a bit blurred. Francisco Macias Nguema, the president of Equatorial Guinea from 1968 to 1979, felt “uneasy” around wealthy, intel- lectual individuals; as a result, he ordered all who wore spectacles killed (Daniels, 2004). Hindsight suggests that Nguema showed a hint of paranoia, as his beliefs more closely resembled delusions and fear. In another case many are familiar with, Adolf Hitler proposed a plan to eradicate all those that do not belong to the Aryan race, a race he believed was ostensibly greater than others; not many would now judge Hitler as sane, rather extreme in his delusions (Lothane, 1997).

Why bring up seemingly random cases demonstrating the psychopathologies of leaders accused of horrendous crimes such as genocide? One reason is that since there is more than one example, it is unlikely that it is a mere coincidence, although it is not necessarily the norm. Another reason is that atrocities such as genocide and mass killings continue to present day and because each harnesses its own prejudices and beliefs, be they political or religious, it is difficult to come to a common link. In 2008, Stephen K. Baum wrote a book, "The Psychology of Genocide: Perpetrators, Bystanders, and Rescuers," in which he proposes the idea that "a lack of maturation and an abundance of social identity" are leading causes of individuals that perpetuate such crimes. The infamous studies by Milgram and Stanford have delved into the possible rationale for those individuals that supported these actions, and going back to Freud can create numerous theories regarding all of the aforementioned individuals. I propose a close psychopathological examination of one of the most ruthless dictators of the 20th century, Joseph Stalin. A look into his life and how it formed, or perhaps accentuated, his beliefs and noting links, if any, to psychopathology, may create a different perspective from which to address current atrocities. As Stalin once said, "one death is a tragedy; one million is a statistic"; perhaps there are underlying reasons that can reveal the formation of such contemptuous values.

\section{Examining the Psychopathology of Joseph Stalin}

People who have made positive impacts throughout history are remembered as respectable and those who have made nega- 
tive impacts as decadent. A person's impact is commonly characterized as good or bad by judging the effects of his or her actions and decisions. Oftentimes, differing viewpoints create controversy regarding the nature of the impact. Such questions arise when examining the tremendous influence of Joseph Stalin. Many consider Stalin to be the man accountable for the drastic modernization and industrialization of the former Soviet Union (Service, 2001). Others bring attention to the fact that the mass killings and reign of fear that Stalin fashioned are the most dominant aspects of his impact. Some believe he did what any person would do to preserve power, while still others assert that his personal pathologies were responsible for his actions (Service, 2001; Conquest, 1991; Trotsky, 1937).

\section{Childhood and Development}

Joseph Stalin was born Iosif Vissarionovich Dzhugashvili in the republic of Georgia around the year 1879, the only surviving child of Vissarion and Yekaterina Dzhugashvili.

At the time of his birth, Georgia was still a relatively new Russian annex, and discrepancies regarding the exact date and location of his birth are partially attributed to the on-going Georgia-Ossetian conflict. Grigory Zinoviev, later a prominent figure in Stalin's political quests, accentuated his background in describing him as a "bloodthirsty Ossetian." The significance of Stalin's Georgian background manifests itself in numerous respects throughout his life.

Both Vissarion and Yekaterina were listed as serfs, and what limited information is available regarding Stalin's childhood contends that it was of a common peasant's lifestyle. What such a childhood entails is violent outbursts following alcohol intoxication, generally from the father and aimed at both mother and child. Strained relationships between fathers and sons, husbands and wives, and consequently differing goals for children set up conflict within families. If one were to adhere to the psychoanalytic contention that a person's childhood strongly influences his or her personality, it is plausible to argue that Stalin's violent tendencies developed as a result of his father's behavior (Freud \& Strachey, 1962); paranoia is said to oftentimes enter within a maladaptive relationship with the father (Shapiro, 1965; Laughlin, 1967; Meissner, 1986). The aforementioned are just a few of numerous theories that may be used to explain Stalin's personality, and although there may be credibility to them, it is important to not overestimate the influence of childhood environment and attribute this singular circumstance as the cause of possible psychopathology (Renaud \& Estess, 1961).

Ioseb suffered from a nearly fatal bout with smallpox at age 4 and thereafter had a severely pocked face, which was always retouched in photographs; blood poisoning at age 9 was brought on subsequently to being run over by a carriage, an accident which gave Stalin a permanently disfigured and much shorter left arm (Birt, 1993). Being subject to such devastating family conditions, Dzhugashvili's mother believed that he would profit from a religiously oriented education, and in 1888 "Soso," as Stalin was now called, began attendance at the Gori Church School (Conquest, 1991). Physical defects commonly affect one's self-esteem and prosperity, and the aforementioned physical markings were seen as an added insult to injury, as Stalin was already apprehensive regarding his 5' 4 " stature. It is commonly documented that while at the Gori Church School, Soso read "The Patricide" by Alexander Kazbegi, in which the hero, Koba, was the archetypal defender of the "underdog”. It followed that Ioseb identified with the character of Koba and demanded that everyone call him "Koba," a name by which he was known until the Revolution (Tucker, 1973). Meissner (1986) notes that the use of "tough-guy" names is not uncommon among paranoids, an action prevalent in Stalin's life from a young age.

When Stalin became ten years old, Vissarion took him to work at a shoe factory, the only record of any manual labor he encountered; shortly after, Yekaterina intervened and persuaded both toward the importance of an education and he was reenrolled at the Gori Church School (Conquest, 1991). Stalin's father was rumored to have passed away shortly after, a result of a bar-fight in 1909, leaving the family to fend for themselves. Notwithstanding continued tumultuous circumstances, Stalin was a good student and was awarded a stipend to attend the Tiflis Theological Seminary, where it was a hope of his mother's that he become a priest (Service, 2001). However, his time at the Tiflis Theological Seminary exposed him to the radical ideas of Karl Marx and his contemporaries. Studying their works provoked Ioseb's own temperament, already aggravated by abuse, to adopt a radical creed: "the object of any struggle is victory” (Conquest, 1991). Ioseb then initiated alterations in his public persona.

\section{Transformation}

The first part of Dzhugashvili's transformation was his attempt to eradicate his Georgian heritage. He changed his name to Joseph Stalin, a Russian name whose stem "stal," or steel, was symbolic of his "new” character (Conquest, 1991; Himmer, 1986). Stalin's makeover promoted him politically, and helped him maneuver through the ranks of various political parties of the time. In 1912, Vladimir Lenin chose him to serve on the first Central Committee of the Bolshevik Part, which enabled him to play a significant role in the 1917 Bolshevik triumph (Service, 2001). Although the initial relationship between Stalin and Lenin seemed mutually beneficial, both had ulterior motives. While Stalin was using his position to further his own beliefs, Lenin was alarmed and troubled by certain aspects of Stalin's character and personality.

A year prior to his death, Lenin wrote a covert "political testament” in which he disclosed his worried regarding Stalin:

Stalin is too rude, and this defect, though quite tolerable in our midst and in dealings among us Communists, becomes intolerable in a General Secretary. That is why I suggest that the comrades think about a way to remove Stalin from that post and appoint in his place another man who in all respects differs from Comrade Stalin in his superiority, that is, more tolerant, more loyal, more courteous and more considerate of the comrades, less capricious (p. 84).

As history shows, Lenin's warnings went largely unheeded as Stalin continued to gain power and political standing. Stalin recognized the fact that the people were loyal to Lenin and therefore, after Lenin's death, aligned himself closely to him. He held parades, posted doctored portraits of himself and Lenin together at various functions, and even commissioned a movie that depicted Stalin hugging and holding a dying Lenin. When opposition to Stalin's political agenda arose, he regarded his opponents as anti-revolutionary, anti-Leninist, and in that way 
swayed public opinion against the opposition (Conquest, 1991). To maintain his image, Stalin was always hailed as the greatest intellect and creative force in the Soviet Union, perhaps even of all time, and pro-Stalin propaganda became the norm (RancourLaferriere, 1998: p. 17).

\section{Beginnings of Psychopathology}

Underneath a firm façade of power, Stalin found himself struggling with what he believed to be depression; feelings of inferiority, alleged threats to his feelings of grandeur along with various concerns led him to seek help. Vladimir Mikhailovich Bekhterev, a renowned Russian psychiatrist, was summoned to assess Stalin's mental condition (Lerner, Margolin, \& Witztum, 2005). After the critical examination that no one but Bekhterev and Stalin witnessed, Bekhterev said only one word "paranoiac" (Antonov-Ovseyenko, 1981). Nobody knows exactly what happened during this examination other than what Bekhterev disclosed concerning his examination of a "paranoiac with a dry hand"-a clear allusion to Stalin. It is unknown how Bekhterev's response reached Stalin, but it is presumed that when Stalin heard about Bekhterev's opinion, he ordered the death of the person who held such an unwanted opinion of him (Topolyansky, 1989). In 1927, Bekhterev died of an unknown cause, although it is believed that he was poisoned by the order of Stalin. After his death, his name and works were deleted completely from textbooks and scientific literature (Lerner, Margolin, \& Witztum, 2005). In 1929, when addressing the Central Committee concerning his alleged lust for tyrannical power, Stalin dismissed the idea of his personality being an issue by claiming that it had "no real consequence" and was a "trifle" (Tucker, 1974). At the time, the Central Committee accepted Stalin's contention that his personality was irrelevant and inadvertently strengthened his power.

Notwithstanding, Stalin's rise to power did not satisfy his desire for more; rather, it unveiled jealous and paranoid characteristics. At this time, Stalin, although claiming to have rejected his Georgian background, continued following Georgian social standards by limiting his distinction between personal and political relationships with people. He viewed people either as friends that he could trust, or as enemies that he must fight and overcome. Stalin was also incredibly driven to feel jealous of anybody who appeared better than he in any domain, especially those in which he considered himself eminent (Conquest, 1990). Although he was unwilling to accept it, Stalin's behavior exemplified his previous diagnosis of pathological paranoia, an idea supported previously by Meissner (1986).

\section{DSM-IV Assessment}

Bekhterev never explicitly stated the complete diagnosis he gave Stalin, however, comparing his opinion with a logical analysis of Stalin's behavior allows for a more specific conclusion. According to the American Psychiatric Association, the Diagnostic and Statistical Manual of Mental Disorders (DSM$I V-T R$ ) characterizes the core feature of a paranoid personality disorder as a "pervasive distrust and suspiciousness of others... motives interpreted as malevolent” (2000). People diagnosed with paranoid personality disorder are frequently suspicious that other are attempting to exploit them, are preoccupied with doubts about the loyalty of friends and associates, and are reluctant to confide in others with fear that the information will be used against them. They also perceive attacks on their char- acter and reputation that are only evident to themselves (DSM$I V-T R, 2000)$. Using the DSM-IV-TR criteria to characterize the behavior of Joseph Stalin clearly demonstrates that his conduct and rationale is of a persona with paranoid personality disorder.

Stalin's paranoia and desire to stay in power caused him to employ various schemes in order to control the thinking of his fellow politicians as well as the citizens of the U. S. S. R. Although immoral, he was an intelligent man who recognized that the mind must be forged at an early age (Tucker, 1974). To follow this ideology and ensure that all children under his regime would be conformed to the Communist lifestyle as early as possible, he created an interest group for them. In the "Pioneers,” membership was not voluntary; rather, it was mandated. Through this group, children were taught about Lenin and Stalin's "greatness" and the need for a Communist lifestyle (Service, 2001). They were also encouraged to bestow the same information to their friends and families and to report any disparate activity and thinking to a specialized police unit created by Stalin. Stalin enforced rigorous laws that condemned disapproval of the government by enforcing severe penalties; those that revealed individuals who did not agree with the Communist agenda were rewarded (Conquest, 1990).

Much of Stalin's regime concentrated on appeasing his paranoia, compounded by excessive consumption of alcohol. This led him to act impulsively and dispose of anyone who did not fit his idea for a "greater Soviet Union" (Conquest, 1991). He was responsible for the extermination of various social groups and political leaders of opposing parties; most of his appointed cabinet was "disposed of" within several years of their appointments (Tucker, 1974). In spite of this, his behavior and perceived beliefs did not cause him to question his idealized image of himself. While failure to perceive one's flaws is a common human trait, Stalin's case was extreme due to his intolerance of anything short of perfection in himself. This caused him to control the information that others received regarding him and his regime, by means of intimidation and altering literature (Clarfiend, 2002). As previously mentioned, even pictures were doctored as to conceal any physical flaws he may have had. Due to the harsh consequences Stalin instigated for any who contradicted him, most people learned to accept the favored opinion rather than risk punishment or death.

Nikolai Bukharin, a former ally of Stalin who was later renounced as result of a disagreement concerning collectivization, furthered the concept of Stalin's paranoid insecurity. He observed that Stalin was unhappy at not being able to convince everyone, including himself, that he was greater than everyone else was (Volkogonov, 1988). The paranoia that Stalin experienced was not limited towards others, rather it included him; this is allegedly caused by his suspicion that he is not as great as he believes himself to be. This made Stalin dependent on the attitude of others, believing that if they see him as a hero-figure, then it is so (Volkogonov, 1988). This was one of the reasons for his control over the media, literature and people's rights. Stalin ignored the fact that he was compelling them to think he was great, and wallowed in the illusion of people's admiration for him (Conquest, 1990).

\section{Culmination(s) of Psychopathology}

The combination of paranoid personality disorder, alcohol abuse, intelligence, and a cruel nature created the foundation 
for Stalin's infamous mass killings. Stalin controlled everybody through fear-fear of death, fear of torture, fear of exile. His belief that everyone was plotting against him contributed to him forcing "confessions" out of many innocent people; he felt that if he had a scapegoat, then he was closer to eliminating the prospect of his defeat (Volkogonov, 1988). To ensure his power, he enforced the "Russification" of the Soviet Union, which included rejecting Christianity's God and creating the Secret Police. It is alleged that Stalin imprisoned religious leaders that believed in Christianity's God because "he was a godlike figure to himself" and did not want competition, even from religion (Tucker, 1974). People began fearing the Secret Police more as they were now prosecuting people for religious reasons as well as political ones; they would now torture people psychologically as well as physically (Tucker, 1974).

The methods Joseph Stalin implemented throughout his rise and maintenance of power of the Communist Party in the former Soviet Union are clearly linked to his psychological pathologies. Stalin's vicious tactics, coupled with his depression, extreme paranoia, and liberal alcohol use elevated his image to that of more that just a dictator; he became the face of evil. His name became synonymous with Hitler as a merciless tyrant who had little concern for the value of human life. The effects Stalin had on the former Soviet Union are still present today, not only in the new Russian Federation but also around the world. The life and impact of Joseph Stalin is an unmistakable example of the outcome of an altered psyche, unfortunate childhood, and a destructive persona.

\section{Ramifications of Examining Psychopathology}

This paper has not touched on war, although it is an extremely violent act, due to its emphasis on the actions undertaken by single leaders. Arguably, no single individual has committed atrocities such as genocide single-handedly, but the strong beliefs and pathologies they may possess have motivated them to bestow their ideas unto others. The psychopathology of Joseph Stalin is a single case study attempting to find reasons other than political and economic motivations for such horrid actions. As mentioned in the beginning, Nguema demonstrated a fairly extreme paranoia, a psychopathology that led to the purging of many. Perhaps looking at genocide and similar atrocities by way of the instigator's psychopathology will present a new mode of prediction, and prevention.

\section{REFERENCES}

American Psychiatric Association (2000). Diagnostic and statistical manual of mental disorders (Revised 4th ed.). Washington, DC: American Psychiatric Association.
Antonov-Obseyenko, A. (1981). The time of Stalin. Portait of a tyranny. New York: Harper \& Row.

Baum, S. (2008). The psychology of genocide. New York: Cambridge University Press.

Birt, R. (1993). Personality and foreign policy: The case of Stalin. Political Psychology, 14, 607-625. doi:10.2307/3791377

Clarfield, A. M. (2002). The Soviet doctor's plot-50 years on. British Medical Journal, 325, 1487-1489. doi:10.1136/bmj.325.7378.1487

Conquest, R. (1990). Stalin: Breaker of nations. New York: Penguin Book.

Conquest, R. (1991). The great terror: A reassessment. New York: Oxford University Press.

Daniels, A. (2004). If you think this one's bad you should have seen his uncle. The Telegraph, August 29.

Freud, S., \& Strachey, J. (1962). The ego and the id. W.W. Norton \& Company.

Freud, S. (1959). The collected papers. London: Basic Books.

Himmer, R. (1986). On the origin and significance of the name Stalin. The Russian Review, 45, 269-286. doi:10.2307/130111

Holocaust Encyclopedia (2013). What is genocide? Retrieved from United States Holocaust Memorial Museum.

http://www.ushmm.org/

Laughlin, H. (1967). The neuroses. Washington: Butterworths.

Lerner, V. \&. Witztum, E. (2005). Vladimir bekhterev. American Journal of Psychiatry, 162, 1506. doi:10.1176/appi.ajp.162.8.1506

Lerner, V., Margolin, J., \& Witztum, E. (2005). Vladimir Bekhterev: His life, his work and the mystery of his death. History of Psychiatry, 16, 217-227. doi:10.1177/0957154X05049611

Lewin, M. (2005). Lenin's last struggle. University of Michigan Press.

Lothane, Z. (1997). Omnipotence, or the delusional aspect of ideology, in relation to love, power, and group dynamics. The American Journal of Psychoanalysis, 57, 25-47. doi:10.1023/A:1024622504975

Mamdani, M. (2007). The politics of naming: Genocide, civil war, insurgency. London Review of Books, 29, 1-8.

Meissner, W. (1986). Psychotherapy and the paranoid process. Northvale, NJ: Jason Aranson.

Rancour-Laferriere, D. (1988). The mind of Stalin: A psychoanalytical study. Ann Arbor: Ardis.

Renaud, H., \& Estess, F. (1961). Life history interviews with one hundred normal American males: Pathogenicity of childhood. American Journal of Orthopsychiatry, 31, 769-802.

Service, R. (2001). A history of twentieth-century Russia. Cambridge, MA: Harvard University Press.

Shapiro, D. (1965). Neurotic styles. New York: Basic Books.

Topolyansky, V. (1989). Noch' pered rozhdestvom v 1927 godu [The night before Christmas in 1927]. Ogonyek, 27, 9-10.

Trotsky, L. (1937). Stalinskaya shkola falsifikatsii [Stalin's school of falsification, Abr.]. Pioneer Publishers.

Tucker, R. (1974). Stalin as revolutionary. New York: W.W. Norton \& Company.

United Nations General Assembly (1948). Convention on the prevention and punishment of the crime of genocide. New York: United Nations.

Volkogonov, D. (1988). Stalin: Triumph and tragedy. London: Grove Weindenfeld. 